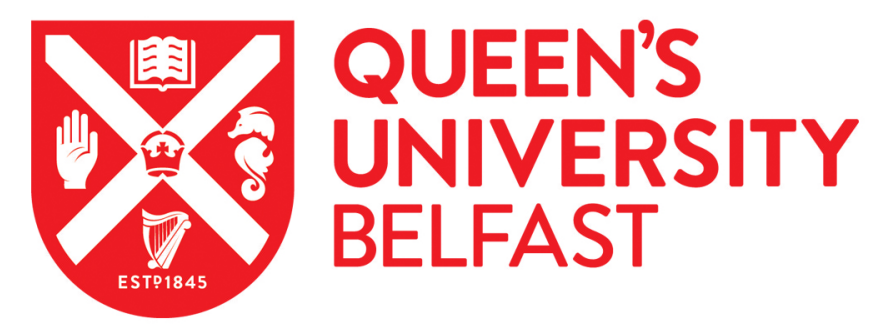

\title{
Bilingual Education and Language Policy in the Global South
}

McKendry, E. (2015). Bilingual Education and Language Policy in the Global South. Policy \& Practice: A Development Education Review, (20), 207-212. http://www.developmenteducationreview.com/isssue20-review3

Published in:

Policy \& Practice: A Development Education Review

Document Version:

Publisher's PDF, also known as Version of record

Queen's University Belfast - Research Portal:

Link to publication record in Queen's University Belfast Research Portal

Publisher rights

Copyright 2015 Centre for Global Education

\section{General rights}

Copyright for the publications made accessible via the Queen's University Belfast Research Portal is retained by the author(s) and / or other copyright owners and it is a condition of accessing these publications that users recognise and abide by the legal requirements associated with these rights.

Take down policy

The Research Portal is Queen's institutional repository that provides access to Queen's research output. Every effort has been made to ensure that content in the Research Portal does not infringe any person's rights, or applicable UK laws. If you discover content in the Research Portal that you believe breaches copyright or violates any law, please contact openaccess@qub.ac.uk. 


\section{Bilingual Education and Language Policy in the Global SOUTH}

Jo Arthur Shoba and Feliciano Chimbutane (eds.) (2013) Bilingual Education and Language Policy in the Global South, New York and London: Routledge.

\section{Review by Eugene McKendry}

This volume is the fifth in the Routledge Critical Studies in Multilingualism series, under the series editorship of Marilyn Martin-Jones of the MOSAIC Centre on Multilingualism, University of Birmingham, UK. The stated aim of the book is to investigate a variety of ways in which bilingual programmes can 'make a contribution to aspects of human and economic development in the global South'. The book has two sections: the first, titled Language-inEducation Policy across Cultural and Historical Contexts, presents case studies from Peru, Ghana, Eritrea, Morocco, East-Timor, Ethiopia and Mozambique; the second, titled The Making and Remaking of Policy in Local School and Classroom Contexts, discusses Laos (LPDR), Haiti, North India and Botswana. The reader is well served by the editors whose introduction is supported by discussants' responses to each section (Kendall A. King and Angel Mei Yi Lin) and an 'Afterword' by Casmir M Rubagumya.

Research into educational language policy at regional and national levels is the focus of Section 1, while bilingual and multilingual classroom processes are the primary focus of analysis in Section 2. There is, however, no clearly defined cleavage between these two approaches. They both take into consideration the interrelationship of language policy and planning (LPP) and classroom practice, not necessarily as two sides of a coin, but as essentially overlapping processes.

The book illustrates the fact that the global South encompasses significant cultural, political, and economic differences and tensions. Nevertheless, while context-specific conditions will always come into play, 
each one of the eleven case studies presented evidences the universal globalisation influences and pressures exerted by the historical and economic dominance of the global North and the post-colonial legacy. The relationship between policymakers, often representing the aspirations of an elite, and those who are charged with implementing the policy, the teachers in the classroom, is often a distant one. As Lin says in her discussion:

"The imposition of a standardized official language, whose speakers are typically the political elite of the state, is justified in the discourses of national development, often crystallized into the catch words of 'internationalization' and 'globalization"' (225).

If the classroom practitioners are not involved in policymaking, or do not fully share the aims and goals of policy, the likelihood of the top-down policymakers seeing their goals coming to fruition is significantly diminished. In the final analysis, teachers have their particular sphere of influence, the classroom itself, which is where language teaching, languagein-education (LIE) policy and practice are ultimately realised, rather than in ministries of education, often distant in space and mindset.

The various chapters describe how, on the one hand, there is a tendency to encourage, or in some cases enforce, a centripetal (Bakhtin, 1981) tendency towards linguistic uniformity nationally and globally, while on the other hand there is a centrifugal tendency to assert local identities. Postcolonial nation-building is a common denominator in much of the global South. While postcolonial nation-building policies might aspire to the recognition of local languages as a response to a colonial policy of homogenisation (for example Peru), a policy of fostering national unity through language homogeneity in post-colonial nation-building is evident elsewhere (for example Botswana). The tensions arising from such postcolonial nation building in a globalised world are highlighted in these discussions of language education and policies. It is commonplace, for example, for the former colonial language to be adopted as the national language after independence to cement national unity and loyalty among 
different ethnic groups. In such circumstances, where borders had been drawn by colonial masters rather than along coherent ethnic and linguistic lines or natural geographic barriers, internal multilingualism is seen as a potential source of tribal tensions and regional rivalry and as a barrier to participation in the globalised economy. This can result in newlyindependent states resorting to the ideologies and discourses of their formal colonial masters, including the promotion of an official state language.

In Mozambique, the colonial power in Lisbon had imposed Portuguese as the language of administration and civilisation (126) and upon independence in 1975 Frelimo (Mozambican Liberation Front) made Portuguese, the former colonial language, the official language of the country as the language of national unity (língua da unidade nacional). Multilingualism was conceptualised as a source of tribalism and regionalism and was to be vigorously opposed (127). Since then, however, with constitutional reforms in 1990 and 2004, 'the state values the national languages as a cultural and educational heritage and promotes their development and increased use as vehicles of our identity' (Constitution of the Republic of Mozambique, 2004: 7 quoted in Chapter 1). Such shifting sands of language policy in the global South run through the book. In reality, in the linguistically diverse contexts discussed in the book, trilingual provision for a home or local, regional language and a national language, whether indigenous (e.g. Amharic in Eritrea) or colonial (e.g. Portuguese), is complicated by increased pressure towards English (104).

The dominance of English as a global lingua franca is a recurring theme, with the international spread of English 'palpably obvious', even in the most remote regions (105). In former British colonies, such as Ghana and Botswana, the push for English in the education system and society would be classified as a subtractive, submersion language policy, in contrast to the 'additive multilingual approach' policy for local languages in other chapters such as that on East Timor (96). Although English has the status of national official language in Botswana, not many people are competent in the language (214). The promotion of English in the classroom is often 
tantamount to 'policing' (212). 'Nation building was the altar at which ethnic and linguistic diversity was to be sacrificed' (209, citing Englund, 2003). Overtly in Botswana and Ghana, and at a remove in other chapters, 'the underlying point is that English, as the main language of globalisation, is the window through which [the global south] interacts with the international community' (209).

Another recurring theme throughout the book is the layered onion metaphor for LPP, proposed by Ricento and Hornberger (1996) and developed in Hornberger and Johnson's (2007: 509) call for 'more multilayered and ethnographic approaches to language policy and planning'. Many authors in the book use the metaphor to illustrate how language policy and planning in education is played out at different levels: 'In this way, the complex interlinkages among levels - national, institutional, and interpersonal - are acknowledged, and policy making is viewed as not only top-down but also bottom-up' (2).

The book illustrates the tension between harmonisation and pluralism (233), where forces that would like to foster national unity through a policy of 'one country one language' confront those advocates of pluralism who wish to see minority and local languages being recognised and valued. While the editors acknowledge a feeling of déjà vu in considering the individual case studies, this is seen as a strength, not a weakness, when considered as a whole. The overwhelming message emerging is a positive one, emphasising the value of bi/multilingualism on the ground, within and for communities, even if the pressures for the perceived benefits of globalisation are growing. But as Ricento (2006: 8) observes, 'Language policy debates are always about more than language'.

This volume also serves to hold up a mirror to language policy and education in the global North, where similar diversity of language policy and practice can be found across jurisdictions. How do Western(ised) states treat the indigenous regional and minority languages which have historically and currently been seen as a challenge and threat to the nation-state? One can 
compare and contrast, for example, the hegemonic intolerance of linguistic diversity in France, typified, for example by the assertion in 1925 by the then Ministre de l'Instruction Publique, Anatole de Monzie, but still followed today, that 'Pour l'unité linguistique de la France, la langue bretonne doit disparaître' ('for the linguistic unity of France, the Breton language must disappear') with the more tolerant approach which has emerged in the last few decades in the United Kingdom which recognises and gives place in official policy and education to its regional languages in Scotland and Wales. But even there, negativity flourishes as in Northern Ireland where opposition to the Irish language is so intense in most Unionist circles that it has been dubbed the 'green litmus test of community relations' (Cultural Traditions Group, 1994: 6).

Another challenge to the global North is how it will treat the linguistic diversity arising, in a reversal of direction, from immigrant community languages from the global South and Eastern Europe. The multilayered complexity of the language policy and planning onion will surely grow worldwide and this book provides much food for thought.

\section{References}

Cultural Traditions Group (CTG) (1994) 'Giving voices: the work of the Cultural Traditions Group 1990-1994’, Belfast: Community Relations Council.

Englund, H (2003) 'Introduction: Recognising identities, imagining alternatives' in H Englund and F Nyamnojh (eds.) Rights and the Politics of Recognition in Africa, London: Zed Books.

Hornberger, N H and Johnson, D C (2007) 'Slicing the onion ethnographically: Layers and spaces in multilingual policy and practice', TESOL Quarterly, Vol. 41, No. 3, pp. 509-532.

Ricento, T (ed.) (2006) An Introduction to Language Policy: Theory and Method, Oxford: Blackwell.

Ricento, T K, and Hornberger, N H (1996) 'Unpeeling the onion: Language policy and the ELT professional', TESOL Quarterly, Vol. 30, No. 3, pp. 401-427. 
Eugene McKendry is a Senior Lecturer in the School of Education, Queen's University Belfast. He is also Director of the Northern Ireland Centre for Information on Language Teaching and Research (NICILT). 